\title{
Clarithromycin Treatment for Polymyalgia Rheumatica
}

\author{
Polymyalgia Rheumatica için Klaritromisin Tedavisi
}

Masashi Ohe, Ken Furuya

Department of Internal Medicine, JCHO Hokkaido Hospital, Sapporo, Japan

\section{ABSTRACT}

Macrolide antibiotics, such as clarithromycin (CAM), provide not only antibacterial activity but also anti-inflammatory effects. Several recent studies have reported the successful treatment of rheumatoid arthritis and polymyalgia rheumatic (PMR) using CAM due to its anti-inflammatory effects. Herein, we also report two cases of PMR treated using CAM. Case 1: An 83-year-old man with PMR was treated using prednisolone (PSL) (15 mg/day) and CAM. When muscle pain disappeared and C-reactive protein (CRP) decreased, the PSL dosage was reduced. When PSL was reduced to $5 \mathrm{mg} /$ day, CAM was discontinued. However, following this discontinuation, muscle pain returned and CRP became positive. Therefore, CAM was successfully readministered. Case 2: A 68-year-old woman with PMR was treated using PSL (15 mg/day). When muscle pain disappeared and CRP decreased, the PSL dosage was reduced. When PSL was reduced to 7 $\mathrm{mg} /$ day, muscle pain returned, and CRP became positive. CAM was successfully added and the PSL dosage could be decreased to $5 \mathrm{mg} /$ day. These two cases suggest that treatment using CAM may be effective in some cases of PMR.

Key Words: Polymyalgia rheumatica, prednisolone, clarithromycin Received: 09.18 .2018

Accepted:12.11.2018

\section{ÖZET}

Klaritromisin (CAM) gibi makrolid antibiyotikler sadece antibakteriyel aktiviteyi değil, aynı zamanda anti-inflamatuar etkileri de sağlar. Yakın zamanda yapılan bazı çalışmalar romatoid artrit ve polimiyalji romatizmasının (PMR) antiinflamatuar etkileri nedeniyle CAM kullanılarak başarılı bir şekilde tedavi edildiğini bildirmiştir. Burada, CAM kullanılarak tedavi edilen iki PMR vakasını da bildiriyoruz. Olgu 1: PMR'li 83 yaşında bir erkek hasta prednizolon (PSL) (15 mg / gün) ve CAM kullanılarak tedavi edildi. Kas ağrısı ortadan kalktığında ve C-reaktif protein (CRP) azaldığında, PSL dozu azaltıldı. PSL 5 mg / güne indirildiğinde, CAM kesilmiştir. Ancak, bu devamsızlığı takiben, kas ağrısı geri döndü ve CRP pozitif oldu. Bu nedenle, CAM tekrar uygulandı okundu. Olgu 2: PMR'li 68 yaşında bir kadın PSL (15 mg / gün) kullanılarak tedavi edildi. Kas ağrısı ortadan kalktığında ve CRP azaldığında, PSL dozu azaltıldı. PSL 7 mg / güne indirildiğinde, kas ağrıSı döndü ve CRP pozitifleşti. CAM tedaviye eklendi ve PSL dozu $5 \mathrm{mg} /$ güne azaltılabildi. Bu iki olgu, bazı PMR vakalarında CAM kullanılarak yapılan tedavinin etkili olabileceğini düşündürmektedir.

Anahtar Sözcükler: Polimiyalji romatika, prednizolon, klaritromisin

Geliş Tarihi: 18.09 .2018

Kabul Tarihi:11.12.2018

\section{INTRODUCTION}

Polymyalgia rheumatica (PMR) is an inflammatory rheumatic disease affecting the elderly population. Glucocorticoids (GCs) remain the mainstay of treatment as they drastically improve the clinical presentation. However, approximately one third of patients experience disease recurrence when the dosage is reduced.

Methotrexate (MTX) is considered a promising agent in the treatment of PMR, and in conjunction with $\mathrm{GC}$, it reduces the cumulative $\mathrm{GC}$ dose, the time for $\mathrm{GC}$ discontinuation, and the incidence of relapse. The use of interleukin (IL)- 6 receptor inhibitor tocilizumab as monotherapy and in combination with GC has been reportedly effective and safe for patients with PMR (1). 
Macrolide antibiotics (MACs), such as clarithromycin (CAM), provide antibacterial activity and anti-inflammatory effects. Several recent studies reported the successful treatment of rheumatoid arthritis using CAM as evidence of its anti-inflammatory effects $(2,3)$. We have also reported several cases of patients with PMR who were successfully treated using CAM as an antiinflammatory agent $(4,5)$. Herein, we report two more cases of patients with PMR treated using CAM.

\section{CASE REPORT}

\section{Case 1}

An 83-year-old man presented with severe muscle pain in his neck, shoulders, lower back, hip girdle, and thighs. Muscle tenderness was noted in all of the aforementioned areas. However, swelling and deformity of the joints were not noted. Laboratory findings were as follows: white blood cell (WBC) count, 11,140 $/ \mu \mathrm{L}$ (neutrophils, $85.2 \%$; eosinophils, $0.2 \%$; monocytes, $6.0 \%$; and lymphocytes, 8.3\%); creatine phosphokinase (CPK), $59 \mathrm{U} / \mathrm{L}$ (normal range, 50-210 U/L); CRP, $3.64 \mathrm{mg} / \mathrm{dL}$ (normal value, $<0.30 \mathrm{mg} / \mathrm{dL}$ ); erythrocyte sedimentation rate (ESR), $38 \mathrm{~mm} / \mathrm{h}$ (normal range, $3-15 \mathrm{~mm} / \mathrm{h}$ ); rheumatoid factor (RF), $10.0 \mathrm{IU} / \mathrm{L}$ (normal value, $<15.0 \mathrm{IU} / \mathrm{L}$ ); anti-cyclic citrullinated peptide antibody (a-CCP Ab), $0.5 \mathrm{U} / \mathrm{mL}$ (normal value, $<4.5 \mathrm{U} / \mathrm{mL}$ ); and antinuclear antibody (ANA) titer, less than $\times 40$. Ultimately, the patient was diagnosed with PMR. The clinical course is presented in Figure 1. The patient was treated using prednisolone (PSL) (15 mg/day) and CAM (400 mg/day), simultaneously, owing to its anti-inflammatory effects. Two weeks after initiating PSL in combination with CAM, muscle pain disappeared and CRP decreased to $0.94 \mathrm{mg} / \mathrm{dL}$. The PSL dosage was gradually decreased to 5 $\mathrm{mg} /$ day and a negative CRP without muscle pain was achieved. Because muscle pain disappeared with a negative CRP, CAM was discontinued in order to assess its efficacy while the PSL dosage remained at $5 \mathrm{mg} /$ day. However, two weeks after discontinuing CAM, muscle pain returned and CRP increased to $1.24 \mathrm{mg} / \mathrm{dL}$. In response, treatment using CAM (400 $\mathrm{mg} /$ day) resumed, as an alternative to increasing the PSL dosage. Two weeks later, muscle pain disappeared and CRP decreased to $0.34 \mathrm{mg} / \mathrm{dL}$. Six weeks after resuming CAM, CRP decreased to 0.20 $\mathrm{mg} / \mathrm{dL}$ and no muscle pain was noted.

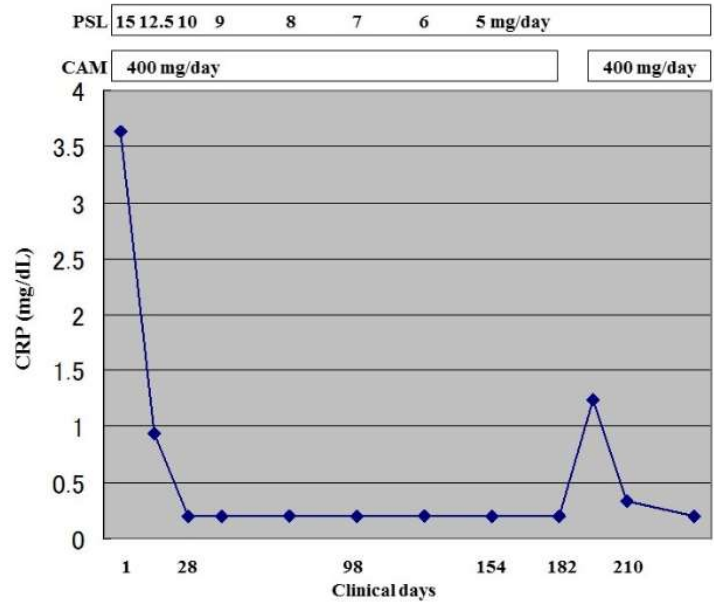

Figure 1. Laboratory data and prescribed agents on clinical days. PSL: prednisolone, CAM: clarithromycin, CRP: C-reactive protein

\section{Case 2}

A 68-year-old woman presented with stiffness and muscle pain in her neck, shoulders, and hip girdle. Muscle tenderness was noted for all of the areas in question. However, swelling and deformity of the joints were not noted. Laboratory findings were as follows: WBC count, 10,080/ $\mu \mathrm{L}$ (neutrophils, $77.4 \%$; eosinophils, 2.4\%; monocytes, 4.4\%; and lymphocytes, 15.5\%); CPK, $110 \mathrm{U} / \mathrm{L}$; CRP, $6.52 \mathrm{mg} / \mathrm{dL}$; ESR, $48 \mathrm{~mm} / \mathrm{h}$; RF, $5.0 \mathrm{IU} / \mathrm{L} ; \mathrm{a}-\mathrm{CCP}$ Ab, $0.5 \mathrm{U} / \mathrm{mL}$; and ANA titer less than $\times 40$. The patient was diagnosed with PMR, and her clinical course is presented in Figure 2. The patient was treated using PSL ( $15 \mathrm{mg} /$ day). Two weeks after initiating PSL treatment, muscle pain disappeared and CRP decreased to $0.79 \mathrm{mg} / \mathrm{dL}$. The PSL dosage was gradually decreased and a negative CRP without any muscle pain was noted. However, when PSL dosage was decreased to 7 $\mathrm{mg} /$ day, slight muscle pain reappeared and CRP increased to $0.86 \mathrm{mg} / \mathrm{dL}$. In consideration of its anti-inflammatory effects and as an alternative to increasing the PSL dosage, CAM (400 mg/day) was initiated in addition to the current PSL dosage. Two weeks after initiating CAM, muscle pain disappeared and CRP decreased to $0.2 \mathrm{mg} / \mathrm{dL}$. PSL dosage could be gradually reduced to $5 \mathrm{mg} /$ day without any sign of recurrence. 


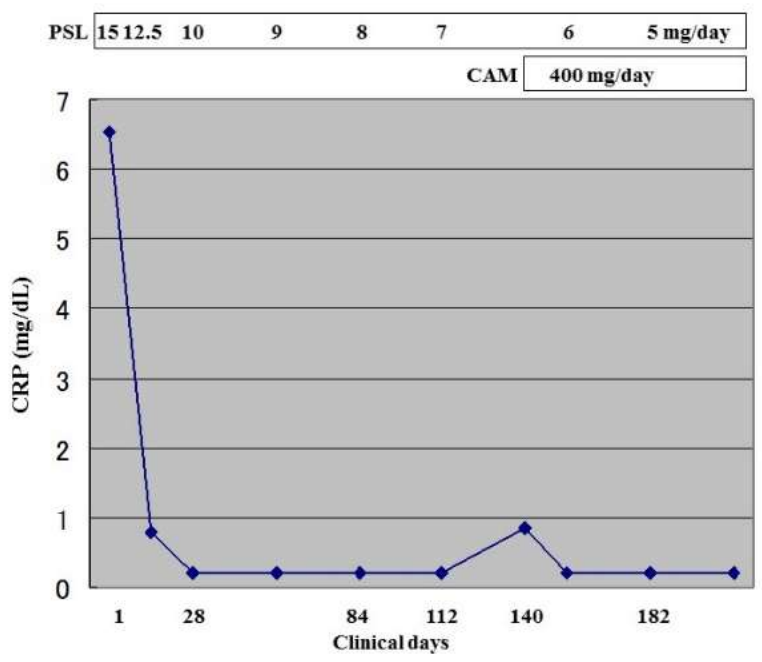

Figure 2. Laboratory data and prescribed agents on clinical days. PSL: prednisolone, CAM: clarithromycin, CRP: C-reactive protein

\section{DISCUSSION}

As stated above, MACs provide anti-inflammatory effects as well as antibacterial activity. In addition, MACs reportedly affect several pathways of the inflammatory process, including the production of proinflammatory cytokines. In fact, CAM inhibits the production of IL-6 (6). Because it has been reported that serum IL-6 levels increase in strong association with PMR disease activity (7), the efficacy of CAM treatment in the present cases might be due to its suppression of IL-6. According to previous reports on CAM treatment for PMR, CAM reduced the required PSL dosage $(4,5)$. Similarly, in the present cases, CAM reduced the required PSL dosage. Moreover, Yamaguchi et al. also reported that CAM reduced the PSL requirements in the treatment of intractable Takayasu arteritis (8). These findings indicate that CAM treatment has steroid-sparing effects. As elderly patients have a tendency to suffer from chronic diseases exacerbated by the use of GC (e.g., diabetes mellitus, osteoporosis, and hypertension), CAM treatment for PMR may help in preventing such effects.

\section{Conflict of interest}

No conflict of interest was declared by the authors.

\section{REFERENCES}

1. Weyand CM, Goronzy JJ. Giant-cell arteritis and polymyalgia rheumatica. N Engl J Med 2014;371:50-7

2. Ogrendik M. Effect of clarithromycin in patients with active rheumatoid arthritis. Current Med Res Opin 2007;23:515-22.

3. Saviola G, Abdi Ali L, Campostrini L, Sacco S, Baiardi P, Manfredi M, et al. Clarithromycin in rheumatoid arthritis: the addition to methotrexate and low-dose methylprednisolone induces a significant additive value-a 24-month single-blind pilot study. Rheumatol Int $2013 ; 33: 2833-8$

4. Ohe M, Bohgaki T. Successful treatment with clarithromycin for patients with polymyalgia rheumatica. Korean J Intern Med 2014;29:539-41.

5. Ohe $M$, Shida $H$, Horita $T$, Oku K. Successful treatment with clarithromycin and/or tacrolimus for two patients with polymyalgia rheumatic. Drug Discov Ther 2017;11:223-5.

6. Khan AA, Slifer TR, Araujo FG, Remington JS. Effect of clarithromycin and azithromycin on production of cytokines by human monocytes. Int J Antimicrob Agent 1999;11:121-32.

7. van der Geest KSM, Abdulahad WH, Rutgers A, Horst G, Bijzet J, Arends $\mathrm{S}$, et al. Serum markers associated with disease activity in giant cell arteritis and polymyalgia rheumatica. Rheumatol 2015;54:1397-402

8. Yamaguchi $\mathrm{K}$, Murashima A, Yamamoto $\mathrm{Y}$. Clarithromycin reduces prednisolone requirements for treatment of intractable Takayasu arteritis. Clin Exp Rheumatol 2004;220:S102. 
